\title{
Abortion pills: under whose control?
}

\author{
Sam Rowlands
}

Honorary Associate Professor, Institute of Clinical Education, Warwick Medical School, University of Warwick,

Coventry, UK

\section{Correspondence to}

Dr Sam Rowlands, Institute of Clinical Education, Warwick

Medical School, Gibbet Hill

Campus, University of Warwick, Coventry CV4 7AL, UK;

sam.rowlands@warwick.ac.uk

Received 30 September 2011 Accepted 22 December 2011

\section{Introduction}

We owe a lot to scientists such as Baulieu ${ }^{1}$ in Paris who developed the progesterone receptor modulator mifepristone and Bygdeman $^{2}$ in Stockholm who conducted early trials of its use in combination with a prostaglandin. Many others have contributed to the development of this drug and to finessing optimal combinations, visit intervals, dosages and routes of administration. ${ }^{3}$ This has given women an entirely new and safe option when requesting an abortion. Novel ways of providing early medical abortion have been developed, especially using non-medical personnel such as nurses or midwives, ${ }^{45}$ or doctors who are not on the premises. ${ }^{6}$

Early medical abortion has a key role to play in reducing unsafe abortion around the world, particularly in resource-poor settings where inadequate surgical services for abortion entail a high risk of infection and reproductive tract injury. ${ }^{7}$ An important signal went out in July 2005, when the regimen of mifepristone and misoprostol was included on the World Health Organization's WHO Model List of Essential Medicines. ${ }^{7}$ The Concept Foundation (http://www.conceptfoundation.org/medical-abortion.php) has registered Medabon ${ }^{\circledR}$ in Cambodia, India and Nepal; this is the first product to package mifepristone and misoprostol together. The Medabon introduction programme aims to launch this dedicated combination pack in 26 low- and middle-income countries.

The Economic Covenant, ${ }^{8}$ Article 15(1) (b), recognises the right of everyone to enjoy the benefits of scientific progress and its applications. With regard to early medical abortion, this must include access to mifepristone and misoprostol.

Who should be involved in controlling these drugs? Health professionals, drug regulators, customs officials, the courts or women themselves?

\section{Criminal law}

In the UK, inducing an abortion surgically or medically comes under the criminal

\section{Key message points}

In almost all jurisdictions, it is a criminal offence to administer or supply medication intended to induce an abortion, unless prescribed by a medical practitioner.

- Fewer than one quarter of countries have licensed mifepristone

- Self-use of misoprostol obtained from pharmacies has reduced abortion-related morbidity and mortality in South America.

- Drugs for medical abortion can be obtained via the Internet or through import for personal use, but this is not legal.

- An Australian couple narrowly escaped jail for selfadministration of non-prescribed drugs for early medical abortion.

- Men who attempt covertly to procure their partners' abortion using medicines will almost certainly be jailed.

- The law on abortion in most countries lags behind scientific developments and needs modernisation.

law. This is the same as in most other countries in the world apart from Canada and two Australian states (Australian Capital Territory and Victoria), where abortion has been decriminalised. ${ }^{9}$

The Offences Against the Person Act 1861, which applies in England, Wales and Northern Ireland, refers to the unlawful administration of any poison or other noxious thing or use of an instrument or other means with intent to procure a miscarriage. Section 58 refers to the woman herself and any other person intending to procure an abortion; Section 59 covers supply or procurement of the means. Section 58 states that for the woman to commit a crime she has to be pregnant but for other persons involved she need not turn out to be pregnant. Some Commonwealth jurisdictions have an Offences Against the Person Act based on British law and many other countries have criminal codes with similar wording. ${ }^{9}$

This criminal aspect tends to have a chilling effect ${ }^{10}$ on both clinicians and the public. Doctors and nurses may fear taking part in abortion care and the public may therefore have to look toward clandestine providers of abortion. Abortion being a crime also contributes towards the stigma attached to it. ${ }^{11} 12$

The Abortion Act 1967 liberalised abortion law in Great Britain, but it does not 
apply to Northern Ireland. The 1967 Act provides a set of defences to the crimes established by the 1861 Act. Section 3A of the Act (created by the Human Fertilisation and Embryology Act 1990 Section 37) gives the Secretary of State for Health the power to approve new classes of place in which a medical abortion may legally take place.

\section{Health care law}

In contrast to criminal law, much modern law relating to abortion comes under the heading of health care. There are numerous examples in the former Soviet Union, Africa and South America of orders or decrees on public health that have improved access to abortion and to its safety. ${ }^{9}$ In France a law was passed a decade ago authorising the use of medical abortion in nonhospital settings. ${ }^{13}$

\section{Licensing of mifepristone}

Mifepristone was first licensed in 1988 in China and France. More than two decades later, there is a widespread lack of availability of medical abortion due to the absence of registration of mifepristone in many countries. So far 46 countries, fewer than one quarter of the total, have approved mifepristone as a registered drug (http://www.gynuity.org).

The company that initially marketed mifepristone in France in 1988, Roussel-Uclaf, suspended production of the drug in order to avoid boycott of its other products by various anti-abortion groups. Following worldwide protests, especially from the World Congress of Gynecologists and Obstetricians, the French Ministry of Solidarity, Health and Social Welfare ordered Roussel to resume marketing and distribution. The French Minister of Health, Claude Evin, maintained that mifepristone was "the moral property of women". ${ }^{14}$

In the USA, Presidents Reagan and Bush Senior managed to stop all research on mifepristone. ${ }^{15}$ The US Food and Drug Administration (FDA) banned the import of mifepristone for personal use in $1989 .{ }^{16}$ The grounds given for this ban were that the drug presented a "threat to public health" and that a demand might be created that would lead to "unsupervised use and/or clandestine distribution". One of the first presidential actions of Bill Clinton, 3 days after assuming office in 1993, was to authorise testing, licensing and manufacturing of the drug within the USA. Political interference with FDA processes resulted in considerable delay in the approval of mifepristone, ${ }^{17}$ but this was eventually given in 2000 .

In 1992, a pregnant US citizen, Leona Benten, attempted to import a dose of mifepristone from France for her own use. The drug was seized from her at airport customs because it was not FDA-approved. A preliminary injunction went in the woman's favour, but at appeal the decision was reversed on technical procedural grounds and the court refused to comment on the appellant's constitutional abortion rights. ${ }^{18}$ Both Judges Stevens and Blackmum dissented from the judgment, holding that the FDA's import alert against mifepristone had imposed an undue burden on a woman's right to select a method of abortion.

In the 1990s, research was conducted on low-dose methotrexate in combination with misoprosto ${ }^{19}$ and this regimen was commonly used in the USA until mifepristone was licensed. However, the use of an antimetabolite is not ideal, with its potential for toxicity and teratogenicity. Methotrexate is still used in Canada as mifepristone has not been approved there to date; Health Canada has received no application for approval, partly due to government inaction. ${ }^{20}$

In some countries such as New Zealand and Australia, although no pharmaceutical company has so far applied for a licence for mifepristone, medical practitioners can import and use it. ${ }^{21}$ In Australia there is an Authorised Prescribers scheme, which allows medical practitioners to prescribe medicines not approved for marketing; this scheme is regulated by the Therapeutic Goods Administration (TGA). ${ }^{21}$ This bureaucratic approach is far from satisfactory and impedes access to early medical abortion. ${ }^{22}$ It now appears, however, that a company may be in the process of applying for a licence. ${ }^{23}$

\section{Licensing of misoprostol}

Misoprostol is a prostaglandin that has been marketed since 1985 for the prophylaxis or treatment of peptic ulcers, for which it is licensed in more than 90 countries. Despite initial strong resistance from the manufacturer, ${ }^{24}$ it is now licensed for reproductive health indications in some countries (http://www.gynuity. org). Taking into account all the evidence about its safety, misoprostol has for several years been listed in Chapter 7 of the British National Formulary (BNF) even though its reproductive health indications are unlicensed. Despite its significantly lower success rate than a mifepristone-misoprostol combination, ${ }^{25}$ misoprostol alone is still a safe, acceptable and reasonably effective method of medical abortion in countries without a mifepristone licence.

Because of its wider and earlier availability compared to mifepristone, and its easy access through pharmacies, ${ }^{26}$ misoprostol alone has had a large positive impact on women's health. For instance, in the late 1980s and early 1990s most clandestine abortions in Brazil were being induced using misoprostol, ${ }^{27}$ a means much safer than traditional methods. ${ }^{28}$ Public condemnation of this widespread use led the Brazilian Ministry of Health to impose severe restrictions on its use in $1991{ }^{29}$ This is a public health paradox, since it is known that such use of misoprostol results in major decreases in morbidity and mortality from severe septic post-abortion complications. ${ }^{27}$ Highly creative programmes developed in Uruguay that provide information about misoprostol before self-use, and follow 
up after abortion, work within existing restrictive laws and have had major health benefits for women. ${ }^{30}$

\section{Obtaining drugs for medical abortion}

In English law it is a crime to supply or obtain any "poison or other noxious thing", knowing that it is intended to be used unlawfully with intent to procure an abortion. A conviction took place in 1880 for the supply of half an ounce of juniper oil to a woman with an unwanted pregnancy. ${ }^{31}$ This remedy did not cause an abortion in that case, but the substance was held to be noxious. Scientific advances have meant that women are now more likely to use a pharmacological agent than traditional remedies or mechanical means.

Women living in jurisdictions with restrictive abortion laws will often seek non-medical means of inducing an abortion. ${ }^{7}$ In contrast to the previous recourse to clandestine operators like Vera Drake in the eponymous 2004 film by Mike Leigh (http://www.imdb. com/title/tt0383694/), women often now turn to the Internet. Some websites offer misleading information; sites that are against the use of mifepristone are more likely to provide incorrect information. ${ }^{32}$ Some sites offer to send the drugs themselves. These may have a medical approach, be online pharmacies or may merely be businesses with no professional input. The cost of the drugs is as little as $£ 15 .^{33}$

Women on Web (http://www.womenonweb.org), which went live in April 2006, ${ }^{34}$ has a thorough medical approach. Women are taken through an online medical questionnaire and the results are checked by a doctor. If no medical contraindications are found, the woman is sent mifepristone, misoprostol and a pregnancy test kit to her home address. Eligible women are restricted to those whose gestation is under 9 weeks and who live in a country with a restrictive abortion law. Thousands of women from 88 countries have now received treatment in this way. ${ }^{35}$

Matters are further complicated by the fact that there are now many other websites being operated that send women unregulated drugs that may be inactive substances, impure products, toxic substances or other substances entirely. ${ }^{36}{ }^{37}$ This is one of the hazards to which the women of Northern Ireland, part of a group of otherwise developed nations, are exposed. ${ }^{38}$

As well as the Internet, there are other sources of abortifacient drugs. These drugs are often imported into the country concerned and sold in shops that are not necessarily pharmacies. One Dublin supermarket was recently fined $€ 5000$ for importing mifepristone from China. ${ }^{39}$ Customs officials regularly intercept consignments of abortifacient drugs. ${ }^{39} 40$

In the Cairns (Queensland, Australia) case, ${ }^{41}$ Sergie Brennan was accused of supplying mifepristone and misoprostol in order to procure his girlfriend's abortion. He had obtained the drugs through the post from his sister in the Ukraine. There was no attempt to smuggle the drugs. Expert evidence was given in court that mifepristone is not harmful or injurious to the health of a woman and that it is listed as an essential medicine by the WHO and approved for use by the Australian TGA. The jury found Brennan not guilty because they were not satisfied beyond reasonable doubt that the combination of drugs was a noxious substance.

\section{Self-administration of drugs by women}

In Britain and in most other countries it is a crime for a woman to attempt to procure her own abortion. However, as we have seen, illegality does not deter large numbers of women from sourcing abortifacient drugs.

In the Cairns case, ${ }^{41}$ the girlfriend, Tegan Leach, was accused of procuring her own abortion with mifepristone and misoprostol. Like her boyfriend, she was found not guilty. It is important to note that because this couple was able to obtain quality products, these were deemed not noxious. If another case were brought in this jurisdiction in which counterfeit drugs or other non-standard treatments were used, then there could be a threat of a custodial sentence. ${ }^{42}$

In the case of Jennie McCormack of Idaho, USA, she asked her sister in Mississippi to buy mifepristone and misoprostol over the Internet and send it to her. ${ }^{43}$ She took the drugs in the second trimester; when she put the expelled fetus in a box on her porch, her sister reported her to the police. She was arrested, but later released due to lack of evidence. Her lawyer secured a temporary court order barring enforcement of the criminal law. ${ }^{44}$ However, if she had been convicted, she would have been imprisoned for between 1 and 5 years.

\section{Nurses and medical abortion}

Many early medical abortion services in the UK are now nurse-led. ${ }^{45}$ Nurse-prescribers should not prescribe mifepristone or misoprostol to induce an abortion as, although the drugs are listed in the BNF, it would be a criminal act for anyone other than a registered medical practitioner to procure an abortion. But nurses can supply and administer the drugs without fear of prosecution. It has been clear since a 1981 House of Lords judgment that nurses may assist in carrying out abortions, provided that a doctor prescribes the treatment, remains in charge and accepts responsibility throughout. ${ }^{46}$ The House of Commons Science and Technology Committee recommended that nurses and midwives should be permitted to sign HSA1 forms (currently signed by two doctors) and prescribe mifepristone and misoprostol, but Parliament did not vote in favour of this in 2008. ${ }^{47}$

In California, the Reproductive Privacy $\mathrm{Act}^{48}$ provides for nurse practitioners, midwives or physician assistants to carry out medical abortions.

\section{Covert administration of abortion drugs}

Helping a willing subject with an unwanted pregnancy to abort is one thing. Covertly trying to induce an 
abortion of a wanted pregnancy without a woman's knowledge is quite another.

A husband, who felt strongly that his wife should not proceed with a pregnancy, sourced abortifacient drugs on the Internet. He laced her food with these drugs on two successive days; on both occasions she had to attend hospital because of uterine cramping pains. However, the 11-week pregnancy did not miscarry; a healthy son was born subsequently. Mr Magira confessed and was prosecuted under Section 58 of the Offences Against the Person Act. His computer hard drive revealed that he had impersonated his wife and used his brother's foreign credit card, attempting to evade detection. He received a custodial sentence of almost 4 years, upheld at appeal. ${ }^{49}$ This was the first case of a potential father attempting to abort a pregnancy in this way.

Dr Edward Erin, a respiratory physician at St Mary's Hospital in London, laced his secretary's drink with methotrexate and Arthrotec ${ }^{\circledR}$ (a combination of misoprostol and diclofenac) in an attempt to induce an abortion. A healthy son resulted from this pregnancy too. Erin was convicted under the Offences Against the Person Act and sentenced to 6 years in prison ${ }^{50}$. He was also subsequently struck off the Medical Register by the General Medical Council. ${ }^{51}$

These cases illustrate how the criminal law will come down hard on involuntary induced abortion, even (especially?) when performed by a medical practitioner.

\section{Discussion}

Although mifespristone or misoprostol might not be registered in a particular country, it is not illegal in many countries to import prescription drugs for personal use. ${ }^{52}$ However, under many criminal codes, abortion is not legal unless carried out by a designated health care professional under specified conditions. In many countries, the woman herself commits a criminal offence if she procures her own abortion. The terms of Women on Web hold the user solely responsible for any violation of their country's law and any ensuing consequences. The position of the doctors who run Women on Web with respect to the laws and the professional regulators of the unknown country from which they operate is uncertain. They may be subject to laws similar to the English legislation on conspiracy to commit an offence abroad. But for many women living in countries with restrictive laws the options are even less safe: they include self-induced abortions with products not regulated as pharmaceuticals or going to clandestine operators who often do not have the requisite skills and do not work in a safe environment.

In the UK, it appears that politicians are not in touch with scientific progress, even when the evidence is presented to them so clearly by their own Science and Technology Committee. ${ }^{47}$ The politicians did not take account of the opinions of leading academic lawyers and ethicists who are agreed that current restrictions on women's reproductive autonomy during the first 24 weeks of pregnancy are not justified. ${ }^{53}$ An opportunity was missed to make some limited amendments to the Abortion Act 1967 via the Human Fertilisation and Embryology Act 2008, ${ }^{54}$ in particular to extend the range of locations where abortions can take place to primary care, to extend the role of nurses and to permit women the choice to be at home to complete early medical abortion. Regrettably, the use of misoprostol at home has still not been approved, despite a powerful evidence base for its safety. ${ }^{55} \mathrm{~A}$ challenge to this stance of the Department of Health before Mr Justice Supperstone failed. ${ }^{56}$ Unless the Secretary of State sees fit to create a new class of place for medical abortion, it appears that a stalemate has developed on this point. Nevertheless, barriers to access to abortion can be overcome by working within existing legal frameworks. ${ }^{57}$

The law in most countries has now become out of step with scientific progress. In order to prevent women in distress with unwanted pregnancies and those who assist them being prosecuted and running the risk of custodial sentences, such laws need modernising. The repeal of criminal laws, as has been done most recently in Victoria, Australia, ${ }^{58}$ is an example of the way forward. Also, there is no solution that will stop the traffic in mifepristone and misoprostol, so avoidance of draconian regulatory responses is needed. ${ }^{42}$

English law on abortion is now decidedly archaic and over-medicalised. ${ }^{53}$ To protect women who experience unwanted pregnancies we should attempt to modernise the law and have in sight an ideal position to aim for. Abortion should be regulated in the same way as any other health intervention; to achieve this the criminality of abortion for doctors and pregnant women should be removed. Sections 58 and 59 of the Offences Against the Person Act 1861 should be repealed, along with the Infant Life (Preservation) Act 1929 in its entirety, the Abortion Act 1967 in its entirety and Section 37 of the Human Fertilisation and Embryology Act 1990, which was not amended by the 2008 Act. A new section of the Offences Against the Person Act would make it an offence for anyone other than a registered health care professional to perform an abortion; this would deal with clandestine abortionists and the likes of Magira and Erin.

Beyond this decriminalisation of abortion in general, however, it is the author's opinion that British women should have the freedom to self-administer mifepristone and misoprostol to induce their own abortions at up to 9 weeks' gestation. The wherewithal for this is now freely available, so this would be a pragmatic advance, in line with contemporary attitudes of many sections of the population. ${ }^{59}$ The role of health professionals in early medical abortion would then solely be to disseminate information on dosage and routes of administration and to provide follow-up in case of complications. Any role for drug regulators, customs 
officials and the courts in self-induced early medical abortion would be abolished.

Some may say that this proposal is unrealistic in view of the political controversy that would be likely to surround such a radical change in the law. But such modernisation has scientific backing as a public health measure and could be used as a model in countries where its benefits to women's health would be even greater.

\section{Competing interests None.}

Provenance and peer review Not commissioned; externally peer reviewed.

\section{References}

1 Baulieu EE, Segal SJ (eds). The Antiprogestin Steroid RU486 and Human Fertility Control. New York, NY: Plenum, 1985.

2 Bygdeman M, Swahn ML. Progesterone receptor blockage. Effect on uterine contractility and early pregnancy. Contraception 1985;32:45-51.

3 Fiala C, Gemzel-Danielsson K. Review of medical abortion using mifepristone in combination with a prostaglandin analogue. Contraception 2006;74:66-86.

4 Kishen M, Stedman Y. The role of advanced nurse practitioners in the availability of abortion services. Best Pract Res Clin Obstet Gynaecol 2010;24:569-578.

5 Warriner IK, Wang D, Huong NT, et al. Can midlevel healthcare providers administer early medical abortion as safely and effectively as doctors? A randomised controlled equivalence trial in Nepal. Lancet 2011;377:1155-1161.

6 Grossman D, Grindlay K, Buchacker T, et al. Effectiveness and acceptability of medical abortion provided through telemedicine. Obstet Gynecol 2011;118:296-303.

7 Rao KA, Faúndes A. Access to safe abortion within the limits of the law. Best Pract Res Clin Obstet Gynaecol 2006;20:421-432.

8 Office of the United Nations High Commissioner for Human Rights. International Covenant on Economic, Social and Cultural Rights. 1966. http://www2.ohchr.org/english/law/cescr. htm [accessed 24 December 2011].

9 Rowlands S. Abortion laws of jurisdictions around the world. 2011. http://www.fiapac.org/media/Divers/Abortion $\% 20$ laws\%20around\%20the \%20world\%20Sam\%20Rowlands\%20 rev\%20June\%202011.pdf [accessed 24 December 2011].

10 Cook RJ, Erdman JN, Dickens BM. Achieving transparency in implementing abortion laws. Int J Gynecol Obstet 2007;99:157-161.

11 Cook RJ, Howard S. Accommodating women's differences under the women's anti-discrimination convention. Emory Law Journal 2007;56:1039-1090.

12 Norris A, Bessett D, Steinberg JR, et al. Abortion stigma: a reconceptualization of constituents, causes, and consequences. Womens Health Issues 2011;21:S49-S54.

13 Law No. 2001-588 of 4 July 2001, Journal Officiel No. 156, 7 July 2001, p. 10823.

14 Dorozynski A. Boycott threat forces French company to abandon RU486. BMJ 1997;314:1145.

15 Sheldon S. Beyond Control: Medical Power and Abortion Law. London, UK: Pluto Press, 1997.

16 Winikoff B, Hassoun D, Bracken H. Introduction and provision of medical abortion: a tale of two countries in which technology is necessary but not sufficient. Contraception 2011;83:322-329.
17 Noah L. A miscarriage in the drug approval process? Wake Forest Law Review 2001;36:571-603.

18 Benten $v$ Kessler 505 US 1084 (1992).

19 Paul M, Lichtenberg ES, Borgatta L, et al. Medical Abortion in Early Pregnancy. Management of Unintended and Abnormal Pregnancy. Chichester, UK: Wiley-Blackwell, 2009:111-134.

20 Erdman JN, Grenon A, Harrison-Wilson L. Medication abortion in Canada: a right-to-health perspective. Am J Public Health 2008;98:1764-1769.

21 Petersen KA. Early medical abortion: legal and medical developments in Australia. Med J Aust 2010;193:26-29.

22 de Costa CM, Russell DB, de Costa NR, et al. Early medical abortion in Cairns, Queensland: July 2006 - April 2007. Med J Aust 2007;187:171-173.

23 Cresswell A. Move for abortion drug RU486 here. The Australian, 1 September 2011.

24 Weeks AD, Fiala C, Safar P. Misoprostol and the debate over off-label drug use. BJOG 2005;112:269-272.

25 Ngoc NT, Blum J, Raghavan S, et al. Comparing two early medical abortion regimens: mifepristone + misoprostol vs. misoprostol alone. Contraception 2011;83:410-417.

26 Billings DL, Walker D, Mainero del Paso G, et al. Pharmacy worker practices related to use of misoprostol for abortion in one Mexican state. Contraception 2009; 79:445-451.

27 Faundes A. Misoprostol: life-saving. Eur J Contracept Reprod Health Care 2011;16:57-60.

28 Costa SH, Vessey MP. Misoprostol and illegal abortion in Rio de Janeiro, Brazil. Lancet 1993;341:1258-1261.

29 Arilha M, Barbosa RM. Cytotec in Brazil: 'at least it doesn't kill'. Reprod Health Matters 1993;2:41-52.

30 Briozzo L, Vidiella G, Rodríguez F, et al. A risk reduction strategy to prevent maternal deaths associated with unsafe abortion. Int J Gynecol Obstet 2006;95:221-226.

$31 R$ v Cramp (1879-80) LR 5 QBD 307.

32 Mashiach R, Seidman GI, Seidman DS. Use of mifepristone as an example of conflicting and misleading medical information on the internet. BJOG 2002;109:437-442.

33 Borland S. 'Backstreet abortion' pills being illegally sold on the internet for just $£ 15$. The Daily Mail, 5 March 2011.

34 Gomperts RJ, Jelinska K, Davies S, et al. Using telemedicine for termination of pregnancy with mifepristone and misoprostol in settings where there is no access to safe services. BJOG 2008;115:1171-1175; discussion 1175.

35 Gomperts R, Petow SA, Jelinska K, et al. Regional differences in surgical intervention following medical termination of pregnancy provided by telemedicine. Acta Obstet Gynecol Scand 2012;91:226-231.

36 Women on Waves. Warning, fakes abortion pills for sale online! 2011. http://www.womenonwaves.org/article-445-en.html [accessed 24 December 2011].

37 Cottingham J, Berer M. Access to essential medicines for sexual and reproductive health care: the role of the pharmaceutical industry and international regulation. Reprod Health Matters 2011;19:69-84.

38 Caldwell J. Internet boom in DIY abortion pills. The Observer, 1 February 2009.

39 Hamilton S. DIY abortion tablets seized. Irish Sunday Mirror, 3 April 2011.

40 Ryan C. Abortion by post. The Irish Times, 15 March 2011.

$41 R v$ Brennan and Leach District Court, Queensland (October 2010) (unreported). 
42 Petersen K. Abortion laws and medical developments: a medico-legal anomaly in Queensland. J Law Med 2011;18: 594-600.

43 Zuckerman L. Woman wins court order against Idaho abortion law. Reuters, 26 September 2011.

44 State of Idaho Legislature Services Office. Idaho Statutes. Title 18: Crimes and Punishments, Chapter 6: Abortion and Contraceptives 18-601 to 18-606. 2011. http://legislature. idaho.gov/idstat/Title18/T18CH6SECT18-604.htm [accessed 24 December 2011].

45 Harvey N, Gaudoin M. Effectiveness of a nurse-led pregnancy termination clinic. Nurs Times 2005;101:34-36.

46 Royal College of Nursing of the United Kingdom v Department of Health and Social Security [1981] 1 All ER 545.

47 House of Commons Science and Technology Committee. Scientific Developments Relating to The Abortion Act 1967. Volume I HC 1045-1. 2007. http://www.publications. parliament.uk [accessed 24 December 2011].

48 California Health and Safety Code 123460 - 123468, Article 2.5: Reproductive Privacy Act. http://leginfo.ca.gov/ cgi-bin/waisgate? WAISdocID $=72114325968+1+0+0 \&$ WAISaction $=$ retrieve [accessed 24 December 2011].

49 R v Gil Magira [2008] EWCA Crim 1939.

$50 R \mathrm{v}$ Edward Erin [2010] EWCA Crim 2093.

51 Dyer C. Doctor who spiked girlfriend's drink to induce abortion is struck off. BMJ 2011;343:d4208.
52 Spain JW, Siegal CF, Ramsey RP. Selling drugs online: distribution-related legal regulatory issues. International Marketing Review 2001;18:432.

53 Sheldon S, Chadwick R, Freeman MDA, et al. Time to modernise abortion legislation. The Times, 17 October 2008.

54 Sheldon S. A missed opportunity to reform an outdated law. Clin Ethics 2009;4:3-5.

55 Ngo TD, Park MH, Shakur H, et al. Comparative effectiveness, safety and acceptability of medical abortion at home and in a clinic: a systematic review. Bull World Health Organ 2011;89:360-370.

56 British Pregnancy Advisory Service $v$ Secretary of State for Health (2011) (unreported).

57 International Planned Parenthood Federation. Access to Safe Abortion: A Tool for Assessing Legal and Other Obstacles. 2008. http://www.ippf.org/en/Resources/Guides-toolkits/ Access + to + safe +abortion.htm [accessed 24 December 2011].

58 Victorian Law Reform Commission. Law of Abortion: Final Report. 2008. http://www.lawreform.vic.gov. $\mathrm{au} /$ home/completed+projects/abortion/lawreform++law+of+abortion_+final+report [accessed 24 December 2011].

59 Ipsos MORI. Public Attitudes Towards Abortion. 2011. http://www.ipsos-mori.com/researchpublications/ researcharchive/2854/Public-Attitudes-towardsAbortion.aspx [accessed 24 December 2011]. 